AperTO - Archivio Istituzionale Open Access dell'Università di Torino

\title{
Translating Hitler's “Mein Kampf”: A corpus-aided discourse-analytical study
}

\section{This is the author's manuscript}

Original Citation:

\section{Availability:}

This version is available http://hdl.handle.net/2318/94147

since 2015-08-12T06:23:16Z

Published version:

DOI:10.1080/17405901003675505

Terms of use:

Open Access

Anyone can freely access the full text of works made available as "Open Access". Works made available under a Creative Commons license can be used according to the terms and conditions of said license. Use of all other works requires consent of the right holder (author or publisher) if not exempted from copyright protection by the applicable law. 
Translating Hitler's "Mein Kampf" A corpus-aided discourse-analytical study, by Stefan Baumgarten. Saarbrücken, Germany, VDM, 2009, 266 pp., £59.90, ISBN 978-3-639-13193-2.

Interest towards the translation of political texts has been growing during the last decade. Modern translation studies has increasingly focused on the complexities of power relations implied by the act of translating, but most of this work dealt with postcolonial literature, while the analysis of political discourse in translation has been explored only recently and by a few scholars.

Translating Hitler's Mein Kampf is a groundbreaking attempt to bring together different disciplines and elaborate an analytical framework to investigate the underlying political and ideological motivations that drive the choices of decision-makers involved in the translation of political texts. As Baumgarten explains, Mein Kampf in translation is a fertile research ground for the study of subtle interrelations of power struggles and ideologies and how they have found their way into textual practices. His choice is certainly felicitous, as the vast amount of material analysed (11 English translations) allows the researcher a wide perspective and the possibility of comparing several translation choices and account for repeated tendencies.

The book belongs to the framework of descriptive translation studies and critical discourse analysis. Its author argues in favour of greater interdisciplinarity between the two disciplines, as both attempt to shed light on hidden ideologies inscribed in language but CDA often limits itself to a monolingual framework and does not account for the subtleties of cross-cultural exchange, while descriptive translation studies is enriched by the insight provided by CDA when dealing with hidden ideologies and power relations. This book convincingly demonstrates what interesting findings Baumgarten's interdisciplinary approach can lead to. Through his innovative corpus-linguistic discourse-analytical model, the author answers his two research questions, namely to what extent competing ideologies and power struggles did determine the English translations of Mein Kampf, given the highly politicised atmosphere of the 1930s and 1940s, and how such ideologies and struggles are reflected on the textual level of the translations.

Readers who do not know German will not be able to understand a few quotations, but their overall understanding will not be hindered. The structure of the book starts from the meta-theoretical, theoretical and methodological foundations, which are outlined in chapter two. This chapter is an informative overview written in a lucid and agreeable style and would also prove a very useful introduction to the disciplines, if used with students. The author then moves to a description of the context in which the book was first written and then translated. Chapter three delineates the sociocultural conditions both in Germany and in the target countries (Britain and the USA) and chapter four narrows the focus down to the level of the translations and provides the immediate context in which they were created, while also introducing the distinction between compliant and resistant translations, which proves helpful further on in the book. Chapters five to seven make use of a corpus-based and corpus-driven approach to scrutinize how ideological struggles and relations of power within the individual translation profiles. Chapter eight reports Baumgarten's conclusions and interesting suggestions for future research.

Most Translation Studies scholars would agree about the necessity of closer cooperation between their discipline and neighbouring ones. Baumgarten's work is a possible answer in that direction, as his findings should be of interest to scholars working in political science or historiography. Moreover, the author highlights his belief in the need for historical research to always have direct social relevance to the present and subscribes to a humanist ontology based on the idea that this world is linked by an essential shared humanity, and the scholar has the ethical duty to work towards the preservation of this precious bond. This attitude shows through in the brilliant way in which he has dealt with what is considered by many the most concrete negation of human rights. This, together with his rigorous analysis and his innovative application of corpus-analytical tools make the book a must for anyone interested in a sociologically oriented approach investigating cross-cultural exchange.

Dr. M. Cristina Caimotto

University of Torino, Italy 